\title{
Parents' motivation in Delivering their children to study at Madrasah Diniyah Awaliyah Alkhairaat
}

\author{
Saripah Saripah ${ }^{*}$, Sagaf S. Pettalongi ${ }^{2}$, and Ahmad Syahid ${ }^{3}$ \\ ${ }^{1}$ Islamic Education Department, Postgraduate, Institut Agama Islam Negeri Palu \\ 2 Islamic Education Department, Postgraduate, Institut Agama Islam Negeri Palu \\ ${ }^{3}$ Islamic Education Department, Postgraduate, Institut Agama Islam Negeri Palu
}

\begin{abstract}
The aim of this study is to find out parents' motivation in delivering their children to study in Madrasah Diniyah Awaliyah Alkhairat Tomado Sigi regency. This study used qualitative method in which the data was gathered through direct observation, in-depth interview with students' parents, and written material. The result of the study shows that the motivation of parents in delivering their children to Madrasah Diniyah Awaliyah School is to increase students' achievement knowledge and religious values. Parents were not only expecting their children to succeed in general subject but also in Islamic religion knowledge and values.
\end{abstract}

ARTICLE

INFORMATION 


\section{Introduction}

In an era of increasingly rapid development of technology and information, and the increasingly intense current of globalization, high quality human resources are required. One of the ways to improve the quality of human resources is through education. Education in the family environment can be done by parents. The family has the main role and responsibility for the care and protection of children from infancy to adulthood. The introduction of children to culture, education, values and norms of social life starts from the family environment. ${ }^{1}$ For the development of a perfect and harmonious personality, children must grow up in a family environment in a climate of happiness.

Parents are responsible for paying attention to children's learning needs, because childrens are humans who must mature. The maturity of a child can be influenced by the responsibility and concern of the parents. ${ }^{1}$

The learning process occurs quickly and effectively if there is motivation. Motivation to learn in children can be built when the teaching and learning process occurs in schools and in the family environment. Motivation in the school environment is carried out by the teacher, while in the

1 Kurniati, Kurniati, Nurdin, Nurdin, \& Nurasmawati, Nurasmawati. (2020). Improving Students' Cognitive and Affective Domains Students through Fostering Teacher Development International Journal of Contemporary Islamic Education, 2(2), 56-70. family environment it is carried out by the parents. ${ }^{2}$

In reality in the field, based on initial research conducted by researchers, it shows that most parents of students do not care about their children's education. For example, when students are given homework, most students do not do their homework because no one accompanies or teaches them at home. This of course greatly affects student learning outcomes.

Researchers

conducted preliminary observations and interviews with class teachers at Madrasah Diniyah Awaliyah (MDA) Alkhairaat Tomado, many of the problems found, including the low level of understanding of the studies or lesson for students in Madrasah. This is evidenced by the amount of many students who do not pass the Minimum Completeness Criteria (KKM), it can be seen from the data on the value of Deuteronomy. The results of learning achievement in students at Madrasah Diniyah Awaliyah (MDA) Alkhairaat Tomado were low. 4 Of the 15 students in the Qiroatul Qur'an subject, only 2 students managed to read fluently, while in the Imlahat subject only 10 students were able to memorize and write. This certainly can illustrate the unsuccessfulness of learning at Madrasahs which can be caused by

2 Evita, Evita, Syahid, Ahmad, \& Nurdin, Nurdin. (2019). Understanding Students' Learning Outcomes Differences Through the Application of the Market Place Activity Type of Cooperative Learning Model and the Application of Conventional Learning Models International Journal of Contemporary Islamic Education, 1(1), 67-85. 
several things, both from the teacher and from the students.

Furthermore, based on interviews conducted with Mr. Bishar and Mrs. Sitti Aminah, there were some students at Madrasah that were unable to attend lessons properly due to the lack of supporting books for students. There were still students who cannot read and write because the parents of these students also cannot read and write. This causes parents to feel indifferent to children's learning motivation at home and leave all responsibilities to the class teacher. Another form of ignorance is that there are some parents who never ask about their child's development because the child is sent to an orphanage due to limited costs and economy in the family. In addition, there are some students who do not pay attention to the lesson when the teacher explains the subject matter (annoying friends and being engrossed in their own activities).

This can be seen from the number of students who are often late for school. Motivation to learn will determine how students will follow the lessons in class. In fact, students are not motivated to take lessons in the Qur'an Hadith, and prefer other lessons such as quiz. Students should get more motivation to continue learning, both from teachers and from parents. Appreciation for learning outcomes is also one way that students can continue to be motivated to become better at learning. This can be done by parents in the family environment.

Based on an interview with $\mathrm{Mr}$. Bishar as the homeroom teacher, students are less active in learning. if asked a question, they would more likely to be quiet than answering the question. In line with this, even in lessons there are only a few students who stand out, other students will be silent and passive.

Such a situation does not develop students' cognitive, affective or psychomotor abilities. In learning, student activeness is needed to make learning successful. Students who are less active in learning are usually because learning does not encourage students to be active. The learning carried out by the teacher is carried out evenly, regardless of individual differences in which there are also different needs. The needs of each student are different, some need to be explained intensively in order to understand the subject matter, some are explained only once to understand immediately. This of course must be considered to stimulate student activeness in learning, lest students who already understand become inactive, and students who don't understand become even more clueless and inactive.

Some other problems that were found when researchers made observations in classroom learning were the teacher's lack of creativity in learning. ${ }^{5}$ Teachers were not able to stimulate students' enthusiasm for learning. The learning that is carried out seems boring because the subject matter is only conveyed through conventional techniques, namely lectures.

Teachers cannot make good use of learning media, as a result students become bored with lessons in class. Teachers still rely on textbooks provided e-ISSN: $2715-4572$ p-ISSN: 2716-1439 
by the government for learning, without creating or looking for new learning materials from other sources. This of course greatly limits students' knowledge of the subject matter. ${ }^{6}$

Some of the problems mentioned above, there are two problems that really stood out, namely the lack of parental attention and low student motivation. Students who are given full attention from their parents tend to have high learning motivation, while students who get less attention from their parents tend to be lazy to learn.

Parents should be able to continuously motivate their children to learn. Parents should give all their attention to their children so that the process of their educational development will be better. ${ }^{3}$ If the child has received all the attention of the parents, both physically and psychologically, the child will automatically be motivated to study harder. Of course, increasing children's motivation in learning will also affect their learning achievement.

\section{Literature Review}

\subsection{Motivation in Education}

Motive is often defined as encouragement. The impulse or energy

${ }^{3}$ Rusli, R. (2020). The Role of Family in Preventing Social Conflict in Society From Islamic Perspectives. Hunafa: Jurnal Studia Islamika, 17(1), 108-122. is a mental and physical movement to act. ${ }^{4}$

So the motive is something that moves humans to behave, and in that action has a specific purpose.

Motivation words are derived from English words, namely "Motivation". The original word was "motive" which the Malay language has also borrowed from "motive", which means effort to encourage someone to do something. Motive can be said as the driving force from within and within the subject to carry out certain activities in order to achieve a goal.

From the discussion above, the writer argues that the words of motivation are meant to cause, aim or impetus, so that someone's goal is actually the main driving force for them to try hard to achieve or get what they want, either negatively or positively.

One of the factors that is quite important is the interest in learning of students, because interest is a determinant of success in achieving educational goals. Interest is a force that encourages individuals to pay attention to certain activities.

The definition of Learning Motivation is one of the factors that determines the effectiveness of learning. A student will learn well if there is a driving factor, namely learning motivation. Students will learn seriously if they have high learning motivation. According to Hamzah B. Uno "learning motivation is internal and external

4 2Azyumardi Azra, Pendidikan Islam "Tradisi dan Modernisasi Menuju Milenium Baru”(Jakarta:Logos Wacana Ilmu ,2000), hlm. 12-13.

e-ISSN: 2715-4572

p-ISSN: 2716-1439 
encouragement to students who are learning to conduct behavior, generally with several indicators or supporting elements. These indicators include: desire and desire to succeed, encouragement and need in learning, hopes and aspirations for the future, appreciation in learning, and a conducive learning environment. " In addition, Winkel said that learning motivation is the overall psychological driving force within students that causes learning activities to achieve a goal. In line with the above opinion, Sardiman A. M, explained that learning motivation is the entire driving force within students.

Motivation is "the driving force from within that causes people to do something or try to meet their needs". Therefore, motivation can also be said: "a series of attempts to provide certain conditions, so that someone wants and desire to do something, if he doesn't like it, then he will try to eliminate or avoid that feeling of dislike."

Motivation is defined as an impetus or driving force that conditions an individual and is then directed to achieve a goal. From some of the opinions above, it can be concluded that motivation is an impetus for someone who comes from inside or outside which functions to direct in carrying out an action. In essence, motivation is closely related to ability, so that people say there is an ability that is contained in a motivated person.

Based on the two theories above, it can be understood that motivation moves a person's heart to try and do so that what they want is achieved and always looks for ways and will not stop trying until what they dreamed of is successfully achieved.

Herzberg's Motivation Theory, there are two types of factors that encourage someone to try to achieve satisfaction and keep away from dissatisfaction. He describes unsatisfactory things as health factors and satisfying things as motivators. This shows that a person is driven to achieve the satisfaction he wants.

Based on the theory above, it can be understood that the factors that encourage a person to achieve satisfaction and keep them away from dissatisfaction.

The two theories above can be understood that effort and satisfaction cannot be separated from human desires because in a person there is always an attempt to see from dissatisfaction and dislike even though they must violate rules that have been prohibited by religion and are regulated by law.

Motivation in someone will manifest a behavior to fulfill a desire or need. Human behavior is basically goaloriented, that is, motivated by the desire to achieve certain goals. ${ }^{5}$ The strong motivation that an individual has will determine the quality of the behavior he displays, both in the context of learning, work and in other life. ${ }^{3}$

The process carried out by a teacher to produce quality graduates is a process that is carried out maximally by involving all elements, sub-subs, parts,

5 Sardiman AM., Interaksi Dan Motivasi Belajar Mengajar (Jakarta: PT. Raja Grafindo Persada, 2007), h. 73 
components or related elements. The teaching and learning process approach must refer to the learning design that has been made, as with learning needs, subject matter, student characteristics, lesson content, assignments, learning objectives, media, support services, evaluation, and student initial tests so that the process will be procedurally mature. ${ }^{6}$

The success of a process is strongly supported by the supporting factors that are around the process (environment), and vice versa, the environment around a good process can interfere with the process where it works optimally.

Benyamin S. Bloom argues that the level of success or mastery is achieved, if the learning is given classically with good quality and various corrective actions against students experiencing difficulties are carried out quickly. Bloom develops teaching patterns and procedures that can be applied in providing instruction to a class. 4

Every action taken by humans always starts with motivation (intention). According to Wexley \& Yulk in As'ad: "Motivation is giving or arising, motive, it can also be interpreted as things or circumstances to become motives". ${ }^{7}$ Meanwhile, according to Mitchell in Minardi: "motivation

\footnotetext{
${ }^{6}$ Rusli, R., Hasyim, M. S., \& Nurdin, N. (2021). A New Islamic Knowledge Production And Fatwa Rulings: How Indonesia's Young Muslim Scholars Interact With Online Sources. Journal of Indonesian Islam, 14(2), 499-518.

7 Moh. As'ad, Psikologi Industri, (Yogyakarta: Liberty, 1998), h. 23.
}

represents psychological processes, which cause it to arise, be directed, and persistence occurs. volunteer activities (volunteers) directed to a specific goal. ${ }^{6}$

Meanwhile, according to Gray in Winardi: "Motivation is a number of processes, which are internal or external to an individual, which causes enthusiasm and persistence in carrying out certain activities". According to Morgan in Soemanto ${ }^{8}$ :

Motivation is related to three things which are also aspects of motivation. These three things; These are: conditions that drive behavior (Mitivating States), behavior that is driven by these circumstances (motivated behavior), and the goals of that behavior (goals or ends of such behavior) 9

Mc Donald in Soemanto defines motivation as a change in energy within a person which is marked by effective encouragement and reactions to achieve goals. Motivation is a complex problem in organizations, because the needs and desires of each member of the organization are different from one another. ${ }^{10}$

This is different because each member of an organization is biologically and biologically unique, and develops on the basis of different learning processes. ${ }^{11}$

\footnotetext{
8 Bean, R, Membantu Anak Agar Berhasil di Sekolah (Jakarta: Bina Rupa Aksara, 1995),h.32

9 Winardi, Manajemen Prilaku Organisasi, (Bandung: Citra Aditya Bakti, 1992).h. 28.

10 Winardi, Manajemen Prilaku Organisasi, (Bandung: Citra Aditya Bakti, 1992).h. 28.

11 Wasty Soemanto, Psikologi pendidikan, (Jakarta: PT Bina Aksara, 1987), h. 28 e-ISSN: $2715-4572$ p-ISSN: 2716-1439
} 
Motivation contains three important elements as suggested by Mc. Donald in Sardiman A.M, namely:

a. That motivation initiates energy changes in each individual human being.

b. Motivation is characterized by the emergence of a person's feeling, affection.

c. Motivation is stimulated because of a goal.

With the three elements above, it can be said that motivation is something complex. Motivation will cause a change in the energy that is in humans, it will cling to the problem of psychological symptoms, feelings and emotions, to then act or do something. All of this is driven by purpose, need and desire.

Motivation questions how to increase passion or enthusiasm, so that they are willing to work hard with all their abilities, proficiency and skills to achieve goals. This motivation is very important, with motivation it is expected that each individual will have the enthusiasm to determine the steps they will take.

Motivating is not an easy job, because it is difficult to determine the needs and wants in himself and in others. Basically, everyone's needs are the same, while the desires of each individual are different because they are tailored to the tastes, habits, abilities, education and environment of each individual.

This is because motivation occurs within but can be influenced from within and from outside. From the description above, it can be concluded that motivation is an impulse caused by stimulation from within or from outside which influences a person to choose or decide on an activity in his life.

\subsection{Parents' Motivation in Child Education}

Parents of biological mothers, fathers, people who are considered old (clever, clever, expert), people who are respected in the village of their parents are people who have mediated our presence in the world. It is through their parents that Allah creates and grows human beings. Parents play an important and influential role in the education of their children. From this expression, parents are responsible for their children's education. Parents are not only mothers, fathers also have a very important role in addition to the duty of earning a living to meet the needs of the family, fathers are also leaders in the family. Fathers and mothers have a great responsibility towards their children. ${ }^{12}$

Parents are part of the family, which is the main basic education place for adults, also where students receive education and guidance from parents or other family members for the first time.

Family is the place to lay the foundations of the personality of students at a young age, because at this age the child is more sensitive to human activities or behavior from where they are, it can be the attention of everyone, thus it can be simply said that motivation is the power that encourages someone to do something to achieve the

12 Noer Aly, Hery., Ilmu Pendidikan Islam, (Jakarta: Logos 1999), h. 87 
goal of goodness, both goodness in the view of religious law and in the view of state law.

Parents are adults who bear the responsibility of education, because naturally children in the early days of life are in the midst of their mother and father. It is from them that children begin to recognize their education. Parents, mothers and fathers, play an important and very influential role in the education of their children.

A father, in addition to having an obligation to earn a living for his family, is also obliged to seek additional knowledge for himself because with that knowledge he will be able to guide and educate himself and his family to be better. Likewise with a mother, in addition to having obligations and family care, she also has an obligation to seek knowledge. This is because mothers are always close to their children.

Thus it is clear that parents have a very large position and responsibility for their children, because they have the responsibility to provide for, educate, nurture, and care for their children to prepare and realize the happiness of children's lives in the future. Or in other words, that parents generally feel responsible for everything from the survival of their children, because there is no doubt that the responsibility for education basically rests on the parents. Wise parents are parents who can foster feelings of joy, joy, happiness, love and so on in their children. While feelings of sadness, anxiety, fear, anger and so on should not be raised by the parents in front of the child in order to build a good relationship with the child.
Meanwhile, hostility, humiliation, hatred, rebuke and so on must be removed in the child's soul, because this attitude is dishonorable. A family is considered a social system, because it has a social system which basically includes beliefs, feelings, goals, rules, positions and roles.

Children are born in the care of parents and are raised in families. Parents serve as caregivers, mentors, nurse, and as educators for their children. Every parent would want their children to be smart, intelligent and have good morals. However, many parents do not realize that their way of educating their children makes them feel neglected, limited their freedom, and some even feel unloved by their parents. These feelings have a lot to do with their attitudes, feelings, ways of thinking, and even intelligence.

Parents in family life have a position as the head of the family or the leader of the household. Parents as the first personal formers in the child's life, the personality of the parents, their attitudes and ways of life are indirect elements of education, which will automatically enter into the child's life. personal children who are growing. ${ }^{34}$ Likewise with children in which they also have human rights which are obtained by birth or presence in community life. Human rights are general (universal), because it is believed that several rights are owned without distinction of nationality, race, or gender. Human rights are also supralegal, meaning that they do not depend on the existence of a constitution, government power, and even have a

e-ISSN: 2715-4572

p-ISSN: 2716-1439 
higher authority, because they come from a higher source (God).

\subsection{Basic Principles of Child Education}

The principle of education is something truth that becomes the basis or foundation of thinking, both at the design and implementation stages of education. The view of human nature is the main focus of thought which is very important in education. One of the main bases of education is that humans can be educated and can educate themselves. As its is well known, humans who are born are almost helpless and highly dependent on others (their parents, especially mothers) but have almost unlimited potential to be developed. Through education, the baby can be developed into an expert candidate who can design and build a spaceship that can explore space, and can create a green revolution ethics with a variety of superior seeds, or vice versa, capable of making bombs that can destroy humans and their culture.

Especially for education in Indonesia, there are a number of principles that give direction in designing and implementing that education. These principles come from both general trends in education in the world and from thoughts and experiences throughout the history of educational efforts in Indonesia. Among these principles, three principles will be studied further in this presentation. The three principles are the principle of Tut Wuri Handayani, the principle of lifelong learning, and the principle of independence in learning. These three principles are considered very relevant to educational efforts, both present and future. Therefore, every teaching staff must understand precisely these three principles in order to properly apply them in the implementation of daily education.

\section{Methodology}

This study uses a qualitative approach with the object of research is a high school in Palu. In this study, the writer took one of the high schools to be the case.

In conducting this research, the researcher chose Madrasah Diniyah Awalia Alkhairaat village Tomado district Lindu as the location where the research was carried out. The researcher chose the location of Tomado village, district Lindu Sigi Regency is due to differences in the motivation and goals of parents to send their children to formal educational institutions at Madrasah Diniyah Awalia Alkhairaat, Tomado village, district Lindu.

The use qualitative methods in this study with several considerations. First, adjusting qualitative methods is easier when dealing with multiple realities. Second, it can directly present the nature of the relationship between researchers and informants ${ }^{13}$. Third, this method is more sensitive and adaptable to the many sharpening of the common

\footnotetext{
${ }^{13}$.Nurdin, Nurdin, Stockdale, Rosemary, \& Scheepers, Helana. (2014a). Coordination and Cooperation in E-Government: An Indonesian Local E-Government Case The Electronic Journal of Information Systems in developing Countries, 61(3), 1-21.

e-ISSN: 2715-4572

p-ISSN: 2716-1439
} 
direction and the patterns of values encountered. ${ }^{14}$

Data were collected using observation techniques, in-depth interviews with the school principla and teachers from the school, and from shared written documents. ${ }^{15}$ While the data analysis is done using reduction and verification techniques with various data sources. ${ }^{16}$ The reduced data is then analyzed by claiming to the theoretical concepts used in this study.

\section{Result and Discussion}

\subsection{Parents' Motivation to send children to Madrasah Schools}

Formal education institutions grow and develop in line with the needs of the local community. Motivation on the quality of education services aims to attract parents to continue their children's education to formal level schools, so that it is necessary to serve and retain them. ${ }^{17}$

14Nurdin, Nurdin. (2018). Institutional Arrangements in E-Government Implementation and Use: A Case Study From Indonesian Local Government. International Journal of Electronic Government Research (IJEGR), 14(2), 44-63. doi: 10.4018/ijegr.2018040104

${ }^{15}$.Nurdin, Nurdin, Stockdale, Rosemary, \& Scheepers, Helana. (2014b, 6-9 Jan. 2014). The Role of Social Actors in the Sustainability of EGovernment Implementation and Use: Experience from Indonesian Regencies. Paper presented at the System Sciences (HICSS), 2014 47th Hawaii International Conference on System Science.

16 Nurdin, Nurdin, \& Aratusa, Zana Chobita. (2020). Benchmarking level interactivity of Indonesia government university websites. TELKOMNIKA Telecommunication, Computing, Electronics and Control, 18(2), 853-859.

17 Dokumen Sekolah tahun 2018
Improving the quality of formal education institutions, including the quality of academic services and the quality of teaching, are efforts that must be made so that student and parent satisfaction as customers of educational institutions can be provided optimally. Following are the results of an interview with one of the informants:

My motivation as a parent in sending children to formal educational institutions, namely: (a) to make children smart and intelligent, (b) to become children that parents are proud of because they go to formal institutions, (c) become children who can lift their dignity and the degree of their parents, (d) can be useful for society and religion, (e) can write, read and count so that they are not fooled by people, (f) get a diploma and can work to help their parents' economy, and $(\mathrm{g})$ can become a civil servant civilian (PNS).18

The author collects answers to motivate parents to formal educational institutions to choose where to continue their education at Madrasah Diniyah Awaliyah Alkhairaat in Tomado village, Lindu district. The following are the results of the interview between parents' motivations for formal educational institutions regarding the choice of places to continue their children's formal education in Taomado village, Lindu district: "I put the child in a formal education institution because the

$18 \mathrm{Hj}$. Fatimah, Orang Tua Anak di Madrasah Dainiyah Awaliya Alkhairaat Desa Tamado, Hasil Wawancara"Tanggal 17 Agustus 2018.

e-ISSN: 2715-4572

p-ISSN: 2716-1439 
education the child gets is supported by adequate facilities"

Based on this question, it appears that the child's parents are more concerned with the educational facilities provided to the child. This shows that parents' motivation towards formal educational institutions prioritizes educational institutions that have adequate facilities in the learning process. The point is with learning facilities in educational institutions, to encourage parents to send their children to these schools

Apart from the motivations above, parents of children send their children to Madrasah Ibtidaiyah Alkhairaat because these educational institutions have teaching staff who they do not hesitate to be experts in their fields.

The following are the results of the interview with the child's parents:

"Personally, I as a parent are motivated to send their children to Madrasah Diniyah Awaliyah Alkhairaat, because the school has selected and has professional teachers in teaching at schools. ${ }^{19}$

Another form of motivation so that parents want to send their children to formal educational institutions at Madrasah Ibtidaiyah Alkhairaat is the process of learning activities. Following are the results of an interview with one of the child's parents:

The formal education institution Madrasah Ibtidaiyah Alkhairaat, which I know in the teaching and learning process between teachers and students,

${ }^{19}$ Hasnidar, Orang Tua Anak di Madrasah Dainiyah Awaliya Alkhairaat Desa Tamado, Hasil Wawancara“Tanggal 17 Agustus 2018 is well managed, because every level of education already has a curriculum that must be achieved so that children do not deviate from studies that is in accordance with the child's mental development.

Likewise, others want their children to study religion well as stated, namely:

"I send my child to MDA Alkhairaat because they have more religions studies, so children can study religion well, nowadays if childrens are not educated since they were a child to study religion, it is difficult for them to understand bad, haram, halal, and so on. The goal is to learn in-depth religious knowledge. , so do good morals and also raise parents, to be pious children. My hope is that my child will become a successful person in the hereafter, can work well, honestly, and wisely". ${ }^{20}$

Based on the results of the interview above, it shows that the motivation of parents towards formal educational institutions is because the learning process at Madrasah Ibtidaiyah Alkhairaat is good so that it becomes the choice of place to continue children's formal education in Tomado village, Lindu district.

There is also one of the motivations for parents to send their child to MDA Alkhairaat, this is as stated by the parents of students that:

"The reason is because in MDA, apart from having more religion studies and more focus on it (religion). The goal is to be able to learn good religion, not to

20 Arbain, Orang Tua Anak di Madrasah Dainiyah Awaliyah Alkhairaat Desa Tamado, Hasil Wawancara"Tanggal 17 Agustus 2018

e-ISSN: 2715-4572

p-ISSN: 2716-1439 
hang out with naughty childrens. His hope is to become a successful person, understand religion well and become a child who is devoted to his parents." 21

Therefore, it is necessary to have a smooth learning process at Madrasah Ibtidaiyah Alkhairaat because it is one of the reasons parents send their children to the school.

Another motivation that makes parents send their children to formal educational institutions is the discipline applied in formal educational institutions. Following are the results of an interview with one of the informants:

My son at home is stressed about discipline. For the educational process I entrust it to formal educational institutions, because formal educational institutions have definitely taught my children about discipline in learning. This can be seen from the development of discipline that I see in children at home. ${ }^{22}$

Based on the results of the interview above, it shows that the motivation of parents towards formal educational institutions is because the learning process at Madrasah Diniyah Awaliyah Alkhairaat is good so that it becomes the choice of place to continue children's formal education in Tomado village, Lindu district. With these results, it is necessary to have a higher level of discipline in educational institutions so that it is one of the

21 Arbain, Orang Tua Anak di Madrasah Dainiyah Awaliyah Alkhairaat Desa Tamado, Hasil Wawancara"Tanggal 17 Agustus 2018

22 Bishar, Orang Tua Anak di Madrasah Dainiyah Awaliyah Alkhairaat Desa Tamado, Hasil Wawancara“Tanggal 17 Agustus 2018 reasons for parents to send their children to these schools.

The issue of low cost is also one of the motivations for parents to send their children to educational institutions. The following is the result of an interview with one of the informants: "With the cost of studying for children without being too burdensome, so I keep sending my child to formal educational institutions. ${ }^{23}$

Based on the responses of the child's parents above, it shows that the motivation of parents towards formal education institutions at Madrasah Diniyah Awaliyah Alkhairaat is due to the lack of funds so that it becomes the choice of place to continue children's formal education in Tomado, Lindu district. Education is a necessity for children to improve their quality of life, so that parents strive to be able to meet the needs of children attending education up to a high level.

Responsibility implies that parents feel there is a moral obligation that must be done sincerely to provide education to their children, so that children can adjust to the society in which they live.

This responsibility is manifested in various efforts, namely: encouraging children to study seriously, providing learning facilities that are needed by children, communicating with various elements related to school education, guiding children to use various learning resources.

23 Ansar Arisandi, Orang Tua Anak di Madrasah Dainiyah Awaliyah Alkhairaat Desa Tamado, Hasil Wawancara"Tanggal 17 Agustus 2018

e-ISSN: 2715-4572

p-ISSN: 2716-1439 
Parents who have motivation and understanding that are in line with the concept of children's education developed in an educational institution will voluntarily contribute energy and emotional thoughts for their children's education. And vice versa, if the understanding and motivation of parents about the concept being developed, there will be doubts to involve themselves both physically and psychologically and emotionally in the provision of education.

Based on some of the above motivations, the motivation of parents towards formal education at Madrasah Ibtidaiyah Alkhairaat towards the choice of place to continue their formal education in Tomado, Lindu District, namely (1) formal educational institutions have adequate facilities, (2) professional teaching staff, (3) ) Adequate teaching and learning activity (KBM) infrastructure, (4) strict discipline and (5) low cost.

\subsection{Parents' Purpose to Send Children to Madrasah Diniyah Awaliyah Alkhairaat}

If you listen wisely about the motivation of parents in Tomado Village in sending their children to formal education at Madrasah Diniyah Awaliyah Alkhairaat, here are the goals of parents in Tomado Village in sending their children to formal education. Following are the results of an interview with one of the child's parents:

In simple terms, I as a parent in sending children to formal education aim to increase understanding to children how important formal education is for their future. And this understanding will be able to improve the learning achievement of the next child or in the future. ${ }^{24}$

From the questions above, the writer concludes that the goal of parents is to improve the future of children in particular and Tomado society in general. Because formal education is important in facing the era of globalization, it needs more special handling of formal education.

This is based on the fact that formal education is one of the areas that must be considered by all parties in realizing national development. Indonesian people who are faithful, cautious and noble character and master science, technology, and art in realizing an advanced, just, prosperous and civilized society based on Pancasila and the 1945 Constitution of the Republic of Indonesia. 25

Therefore, formal education must equip them with various kinds of knowledge, not only theoretically but also practically by giving responsibility and continuing to innovate to find and create new things that are to instill a mental work in children. The following are the results of interviews with the child's parents about the main purpose of sending their children to school:

It is hoped that sending children to school will later go into society,

24 Ansar Arisandi, Orang Tua Anak di Madrasah Dainiyah Awaliyah Alkhairaat Desa Tamado, Hasil Wawancara"Tanggal 17 Agustus 2018

25 Aida, Orang Tua Anak di Madrasah Dainiyah Awaliyah Alkhairaat Desa Tamado, Hasil Wawancara "Tanggal 17 Agustus 2018

e-ISSN: 2715-4572

p-ISSN: 2716-1439 
whatever the form of society, they will not be too clumsy and can adapt easily. Because they are part of society and for society. Because what I know so far is that in formal education it instills in children the belief to study with a holy nature, namely worship to fulfill Allah's commands, to become an intelligent generation. ${ }^{26}$

With parents' understanding of schools or formal educational institutions, Madrasah Diniyah Awaliyah Alkhairaat can create intellectuals. So in this case formal education does not just stop the spirit that there is no dichotomy of religion in general by incorporating lessons into the curriculum. But further making it happen in serious actions to foster these subjects while maintaining religious knowledge that has become characteristic of madrasas because someone who has added knowledge to Madrasah Diniah Awaliyaha or other madrasas, that person's personality will be reflected through his appearance. Following are the responses of parents regarding their goal of sending their children to formal educational institutions:

Personally, my child goes to school at Madrasah Diniyah Awaliyah Alkhairaat because his lessons at the school teach a lot of religious knowledge and morals, then when finished he may also continue to secondary school according to the talents and abilities acquired while sitting in formal educational institutions recognized by the State . Because primary and

${ }^{26} \mathrm{Ibid}$ secondary education is a 9-year compulsory education that has been announced by the government from the previous year, so that a compulsory requirement as a parent is able to foster children to completion for a minimum of 9 years until graduating from junior high school. 27

Based on the results of the interview above, the simple goal of parents sending their children to institutions is on the basis of compulsory education for 9 years, so that it cannot be separated from the goal of the government as the designer and implementer of the 9 year compulsory education process, namely to train children's academic abilities (to be smart).

The statement above is in accordance with the results of an interview with one of the informants who said:

Send my children to formal educational institutions, so I as a parent hope that my child can train and hone the ability to memorize, analyze, solve problems, logic, and so on so that they will have good academic abilities. People who are not good usually do not have good academic abilities so that they can be distinguished from people who go to school. The life that exists in the future is not as easy and beautiful as it is today because it requires struggle and hard work and a lot of knowledge. ${ }^{28}$

Observing from the expectations of the parents of the children above, this

${ }^{27}$ Hasnidar,Orang Tua Anak di Madrasah Dainiyah Awaliya Alkhairaat Desa Tamado, Hasil Wawancara"Tanggal 17 Agustus 2018 ${ }^{28}$ Ibid 
hope can be the goal of those who send their children to formal educational institutions. Because indirectly from this goal, children will experience a process of galvanizing and strengthening mentally, physically and discipline in their later life. The following are the results of interviews with the child's parents about the process their child is experiencing:

Our goal as parents in sending their children to formal educational institutions, we do not mind requiring our children to come and go home according to the applicable rules, so that it can increase our child's discipline. So busy school schedules force children to learn. will continuously strengthen the child's mental and physical health for the better. ${ }^{29}$

Observing the phenomenon of parents' goals in sending their children to formal educational institutions, it can be understood that parents indirectly teach about the achievement processes that children go through, and also introduce responsibility to children. The following are the results of the interview with the child's parents:

As a parent, I am responsible for providing for my family's needs. So that children can feel a responsibility, I purposely send them to form a personality in them of responsibility, namely carrying out their duties properly by going to school diligently

29 Arbain,Orang Tua Anak di Madrasah Dainiyah Awaliya Alkhairaat Desa Tamado, Hasil Wawancara“Tanggal 17 Agustus 2018. which will make parents, teachers, siblings, family, and others proud. ${ }^{30}$

By instilling a sense of responsibility from children, children who go to school can take part in various extracurricular programs as a complement to teaching and learning academic activities in order to develop talents and interests in a person. The more creative skills you have, the better the person's quality will be. Schools and lectures are only as a mediator or selfdevelopment tool. What changes a person is only the person himself. The following are the results of the interview with one of the informants:

The goal of my child being sent to formal institutions is for my child to get experience in life before he is actually involved in society. Because school as a formal institution is a miniature of society. Therefore, at school children will be taught about life in the form of conformity between speech and belief in real life practice), discipline (managing oneself to achieve goals as servants of Allah), social skills (establishing relationships with others), working diligently and perserving accordingly. Islamic law. ${ }^{31}$

Observing the results of the interview with the child's parents above, it appears that this goal must be supported by the condition of the family at home in the process of child

30 Umar Madupa, Orang Tua Anak di Madrasah Dainiyah Awaliyah Alkhairaat Desa Tamado, Hasil Wawancara"Tanggal 17 Agustus 2018

${ }^{31}$ Ridwan, Orang Tua Anak di Madrasah Dainiyah Awaliyah Alkhairaat Desa Tamado, Hasil Wawancara "Tanggal 17 Agustus 2018

e-ISSN: 2715-4572

p-ISSN: 2716-1439 
development, and is the result of the example of the parents to their children. Schools can only forge so that they can become firmly planted and become habits, or test ingrained habits.

Schools as formal educational institutions are not the only pillars that determine children's future. There are many other pillars: family, children's competence, birth talents, and social environment. However, schools can play a more dominant role in shaping character and developing children's competencies. If reality is not so, this is where the parents come in. So children must be mentally and mind ready, while parents must be ready to fulfill all obligations, both costs and active participation in school.

In the implementation of education, it cannot be separated from the goals of parents in sending their children to school. Therefore, one of the goals of parents in general is to send their children to school so that the children will have provision for life now and for life in the future.

Parents of children see that school in the current era is very important for the lives of children now and in the future. Because if they get their education from now on, they will be able to compete with other children who are compatible with it. Especially in the fields of science and technology and IMTAK.

From the opinion expressed by the child's parents above, parents have good goals because they want their children to be able to master knowledge and be able to compete in the world of work.
Through education in formal institutions, children are taught good ways of life, and science of technology. The goal of these parents is that they want their children to know the mastery of knowledge that will later benefit their children's future. Parents always hope that the existence of schools with various formal educational institutions will be useful for fostering the generation of sholih and sholihah. Educators will appear as uswatun hasanah who assist children in achieving their optimal development.

With the growing development of life and the radiation of globalization, education is currently starting to increase the quality of its student resources in various ways. This departs from the many demands of children's parents who expect educational outputs that have capable knowledge and skills that can be actualized in the midst of community life.

Sending children to school as a formal education institution for people is still the choice of parents because they have facilities in the learning process, thus making children busy studying at school and they do not play and wander outside the house after school. With the existence of formal educational institutions, it minimizes outside influence on children in the association so that it can indicate that there are many serious problems for children due to being influenced by the environment outside the home.

Most of the external environment has a negative influence on children and this is a concern for parents of children. Due to the needs of parents who are e-ISSN: 2715-4572 p-ISSN: 2716-1439 
currently busy working outside their homes, by sending their children to formal educational institutions, the children are in school to learn, so that parents are no longer bothered with childcare matters. supervise, and so on.

\section{Conclusion}

Based on the discussion of the results of this study, the authors conclude that the motivation of parents in sending their children to Madrasah Diniyah Awaliyah Alkhairaat that made their parents attracted is because. (a) At the Madrasah Diniyah Awaliyah Alkhairaat educational institution, it produces generations of faith and respect, (b) teaching staff who study accurate Fiqhi, (c) uphold discipline. Then the goal of parents to send their children to Madrasah Diniyah Awaliyah Alkhairaat, Tomado Village, among others, is to increase the thinking of children about the importance of religious education for the future of their children. Then parents also hope their children can contribute to community development both physically and spiritually. Parents also hope that their children will not only have general knowledge but also have good knowledge of Islam.

\section{DAFTRA PUSTAKA}

A.M. Sardiman., Interaksi dan Motifasi Belajar Mengajar, Cet. 10; Jakarta: PT.Raja Grafindo Persada, 2003.

Arikunto. Suharshimi, Prosedur Penelitian Ilmiah, Suatu Pendekatan Praktik Ed.II; Cet IX; Jakarta: Rineka Cipta, 1993.
Azyumardi Azra, Pendidikan Islam "Tradisi dan Modernisasi Menuju Milenium Baru"(Jakarta:Logos Wacana Ilmu,2000.

Abdulsyani. 2002. Sosiologi Skematika, Teori dan Terapan. (Jakarta: BumiAksara).

Bagus. Ide, Pekerjaan Orang Tua dan Implikasinya dalam Kelangsungan Pendidikan Anak, (http:// one.indoskripsi.com), diakses tanggal 20 september 2011

Banawi. Imam, Cendekiawan Muslim Dalam Prespektif Pendidikan Islam, Cet. I; Surabaya: Bina Ilmu, 1991.

Bean, R, Membantu Anak agar Berhasil di Sekolah,Jakarta: Bina Rupa Aksara, 1995.

Depag RI, Alquran dan Terjemahnya, Madinah Munawwarah: Aththiba'a Mushaf Syarif, 1990.

Departemen Pendidikan Nasional RI, Undang Undang Nomor 20 Tahun 2003 Tentang Sistem Pendidikan Nasional, Jakarta: Direktorat Jenderal Pendidikan Dasar dan Menengah Departemen Pendidikan Nasional, 2003.

Departemen Pendidikan dan Nasional, 2012. Kamus Besar Bahasa Indonesia (Jakarta: PT. Gramedia Pustaka Utama).

Djalali, Psikologi Motivasi, Minat Jabatan, Intelegensi, Bakat dan Motivasi Kerja, Surabaya: Wineka Media, 2001.

Djamara, Psikologi Belajar Jakarta: CV. Rineka Cipta, 2002.

Evita, Evita, Syahid, Ahmad, \& Nurdin, Nurdin. (2019). Understanding Students' Learning Outcomes Differences Through the Application of the Market Place e-ISSN: 2715-4572 p-ISSN: 2716-1439 
Activity Type of Cooperative Learning Model and the Application of Conventional Learning Models International Journal of Contemporary Islamic Education, 1(1), 67-85.

Hameyer, Uwe. 1979. School Curriculum in the context of lifelong learning. Hambung: UNESCO Institute for Education.

Hery Noer Aly, 1999. Ilmu Pendidikan Islam, (Jakarta: Logos).

Hamid Patilima. Metode Penelitian Kualitatif. Bandung: Alfabeta, 2013. Indoskripsi, Partisipasi Orang Tua (http:// one.indoskripsi.com), diakses tanggal 20 september 2010.

Kartono, Psikologi Umum, Bandung: Alumni, 1985.

Konselor PKPA Simeulue, Pendidikan orang Tua dalam Mendidik Anak (http:/ / pkpa- indonesia.org), diakses tanggal 21 September 2011.

Kurniati, Kurniati, Nurdin, Nurdin, \& Nurasmawati, Nurasmawati. (2020). Improving Students' Cognitive and Affective Domains Students through Fostering Teacher Development International Journal of Contemporary Islamic Education, 2(2), 56-70.

Margono. S.. Metodologi Penelitia Penndidikan, Cet. IV; Jakarta: Rineka Cipta, 2004.

Maslow, Pssikologi Pendidikan Jakarta: PT Rajawali Citra, 2003.

Milles. Matthew B., et.al, Quqlitative Data Analisis, diterjemahkan oleh Tjepjep Rohendi Rohidi dengan Judul Analisis data Kualitatif, buku
Sumber tentang Metode-metode Baru, Cet,I; Jakarta: UI-Press, 1992.

Moh. As'ad, Psikologi Industri, Yogyakarta: Liberty, 1998.

Moleong. Lexy J., Metodologi Penelitian Kualitatif, Bandung: PT. Remaja Rosdakarya, 2001.

Nanang Martono. Metode Penelitian Kuantitatif : Analisis Isi dan Analisis Data Sekund. Rajawali, Jakarta, 2012.

Nurdin, Nurdin, Stockdale, Rosemary, \& Scheepers, Helana. (2014a). Coordination and Cooperation in E-Government: An Indonesian Local E-Government Case The Electronic Journal of Information Systems in developing Countries, 61(3), 1-21.

Nurdin, Nurdin. (2018). Institutional Arrangements in E-Government Implementation and Use: A Case Study From Indonesian Local Government. International Journal of Electronic Government Research (IJEGR), 14(2), 44-63. doi: 10.4018/ijegr.2018040104

Nurdin, Nurdin, Stockdale, Rosemary, \& Scheepers, Helana. (2014b, 6-9 Jan. 2014). The Role of Social Actors in the Sustainability of E-Government Implementation and Use: Experience from Indonesian Regencies. Paper presented at the System Sciences (HICSS), 2014 47th Hawaii International Conference on System Science.

Nurdin, Nurdin, \& Aratusa, Zana Chobita. (2020). Benchmarking level interactivity of Indonesia government university websites. TELKOMNIKA Telecommunication,

e-ISSN: 2715-4572

p-ISSN: 2716-1439 
Computing, Electronics and Control, 18(2), 853-859.

Nurul Zuriah, Metododologi Penelitian Sosial dan Pendidikan, Jakarta: Bumi Aksara, 2009.

Poerwadarminta. W.J.S., Kmus Umum Bahasa Indonesia, Jakarta: Balai Pustaka, 1984.

Raka Joni, T. 1984. Penelitian Pengembangan dan Pembaruan Pendidikan, Jakarta:P2LPTK Ditjen Depdikbud.

Rahman, Taufik,. 2002. Sosiologi untuk Kelas III SMU, (Jakarta: Yudhistira)

Republik Indonesia, Undang Undang Nomor 20 Tahun 2003 tentang Sistem Pendidikan Nasional, Jakarta: Direktorat Jenderal Pendidikan Dasar dan Menengah Departemen Pendidikan Nasional, 2003.

Rostiawati. Yustina, Tim Penyusun Dasar-dasar Ilmu Pendidikan Jakarta: PT. Gramedia Pustaka Utama, 1996

Robert M. Liebert, Judith Rich Harris. The Child Development From Birth Throught Adolescence, (New Jersey: Prentice Hall 1984).

Rusli, R. (2020). The Role of Family in Preventing Social Conflict in Society From Islamic Perspectives. Hunafa: Jurnal Studia Islamika, 17(1), 108-122.

Rusli, R., Hasyim, M. S., \& Nurdin, N. (2021). A New Islamic Knowledge Production And Fatwa Rulings: How Indonesia's Young Muslim Scholars Interact With Online Sources. Journal of Indonesian Islam, 14(2), 499-518.

Saputra. Alfa, Pecinta Alam dan AkulturasiPendidikan berbasis komunitas adat (http://alfasaputra.multiply.com) diakses tanggal 19 September 2011. Sardiman AM., Interaksi dan Motivasi Belajar Mengajar, Jakarta: PT Raja Grafindo Persada, 2007.

Slameto, 1995. Belajar dan Faktor-faktor Yang Mempengaruhinya, (Jakarta: Rineka Cipta).

Syahril Syarbaini, 2012. Pendidikan Pancasila, Cet. 5, (Bogor: Ghalia Indonesia).

Soerjono, Soekanto, 2004. Sosiologi Keluarga, Cet. 3, (Jakarta: PT : Rineka Cipta).

Syafei, M. Syahlan, 2006. Bagaimana Anda Mendidik Anak: Tuntunan Praktis Orang Tua dalam Mendidik Anak, (Bogor: Ghalia Indonesia).

Satiadarma. Monty P., November 2006 Fungsi Terapeutik Bermain Bagi Anak Usia Sekolah, (On-line), (http://psikoindonesia.blogspot.com), diakses pada tanggal 20 September 2011.

Soemanto, Wasty. 2003. Psikologi Pendidikan Landasan Kerja Pemimpin Pendidikan, (Jakarta: Rineka Cipta).

Sopiah dan Etta. Metodologi Penelitian, Pendekatan Praktis dalam Penelitian Andi.Yogyakarta, 2010.

Surakhmand. Winarno, Dasar dan teknik Research,Pengantar Metodologi Ilmiah, Ed.VI; Cet. II; Bandung:Tarsito,1985.

Syafi'i. Imam, Lembaga Pendidikan Sebagai Agen Perubahan, (http//kangsaviking.wordpress.com), diakses tanggal 21 September 2011. Syarifudin Hidayat dan Sedarmayanti. Metodologi Penelitian, Mandar Maju, Bandung, 2011. 
International Journal of Contemporary Islamic Education

Vol. 3 No. 1 Tahun 2021

Sri Iswati dan Muslich Anshori. Buku

Ajar Metodologi Penelitian

Kuantitatif. Surabaya: Airlangga University Press, 2009. hlm. 13.

Tim Penyusun, Kamus Besar Bahasa Indonesia,Jakarta: Balai Pustaka, 1990.

Wikipedia, Pendidikan Formal (http://id.wikipedia.org), diakses tanggal $28 \quad$ Desember 2011

Winardi, Manajemen Prilaku Organisasi, Bandung: Citra Aditya Bakti, 1992.

Zain, Program Ekstrakurikuler Pendidikan

Agama Islam Pada Sekolah Dasar,

(http://makalahpai.blogspot.com $\triangle$, diakses tanggal 15 September 2011.

e-ISSN: 2715-4572

p-ISSN: 2716-1439 